
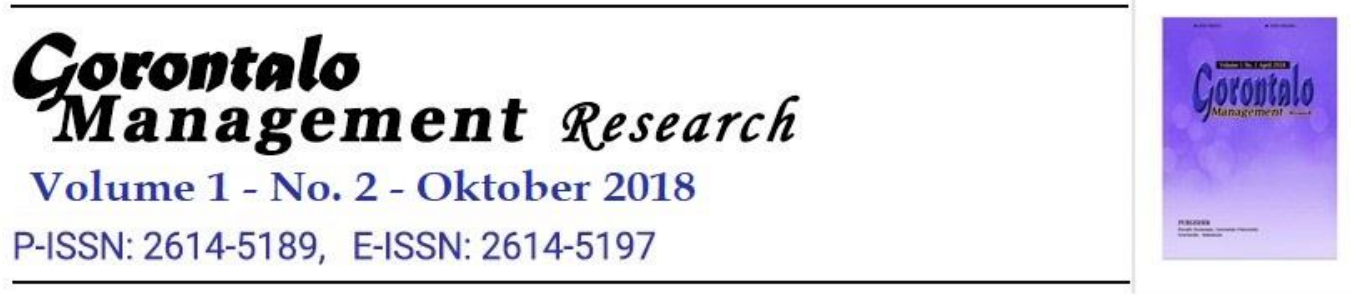

VARIABLES OF INDIVIDUAL CHARACTERISTICS, WORK MOTIVATION, AND BENEFIT SYSTEM TO EMPLOYEE PERFORMANCE IN SUPERMARKET COMPANIES

\title{
VARIABEL KARAKTERISTIK INDIVIDU, MOTIVASI KERJA, DAN SISTEM IMBALAN TERHADAP KINERJA KARYAWAN PADA PERUSAHAAN SUPERMARKET
}

\author{
RAHMISYARI \\ FAKULTAS EKONOMI UNIVERSTAS ICHSAN GORONTALO \\ Email : persadalestari@yahoo.co.id
}

\begin{abstract}
ABSTRAK
Tujuan penelitian yang ingin dicapai adalah untuk mengetahui faktor faktor yang berpengaruh terhadap kinerja karyawan pada enam perusahaan supermarket yang ada di Kota Gorontalo. Sampel penelitian ini adalah 342 orang dari populasi seluruh karyawan yang berjumlah 2367 orang. Teknik pengumpulan data dilakukan wawancara dengan menggunakan model kuesioner serta teknik observasi. Untuk menguji hubungan model digunakan alat analisis yang mampu menjelaskan secara simultan hubungan tersebut yaitu dengan menggunakan path analysis

Hasil penelitian ini mengemukakan bahwa variabel karakteristik individu (X1) secara parsial berpengaruh terhadap kinerja karyawan sebesar 0,619 atau sekitar $61,9 \%$ dan pengaruh variabel motivasi kerja (X2) secara parsial berpengaruh terhadap kinerja karyawan sebesar 0,704 atau sekitar 70,4\%, variabel sistem imbalan secara parsial berpengaruh terhadap kinerja karyawan sebesar 0,724 atau sekitar $72,4 \%$. kontribusi secara bersama - sama (simultan) variabel karakteristik individu, (X1) dan motivasi kerja (X2) dan sistem imbalan (X3) terhadap kinerja karyawan (Y) sebesar $76 \%$ dan sisanya sebesar 24\% ditentukan oleh variabel - variabel lain yang tidak diteliti, yaitu lingkungan kerja, karakteristik organisasi,

Kata Kunci : Karakteristik individu,Motivasi kerja, sistem imbalan dan Kinerja karyawan

\section{ABSTRACT}

The research objective to be achieved is to find out individual characteristics, work motivation and reward system for employee performance in six supermarket companies in Gorontalo City. The sample of this study was 342 people from the population of all employees totaling 2367 people. Data collection techniques were interviewed using questionnaire models and observation
\end{abstract}


techniques. To test the relationship model is used an analysis tool that is able to explain simultaneously the relationship is by using path analysis.

The results of this study suggest that individual characteristics variables (X1) partially affect employee performance by 0.619 or about $61.9 \%$ and the effect of work motivation variables (X2) partially affects employee performance by 0.704 or around $70.4 \%$, system variables partial rewards affect employee performance by 0.724 or around $72.4 \%$. contribution together (simultaneously) variables of individual characteristics, $(X 1)$ and work motivation (X2) and reward system (X3) on employee performance (Y) by $76 \%$ and the remaining $24 \%$ is determined by other variables not examined, namely the work environment, organizational characteristics,

Keywords: individual characteristics, work motivation, reward system and employee performance

\section{Pendahuluan}

Sumber Daya Manusia merupakan aset besar untuk kelangsungan hidup perusahaan saat ini maupun di masa yang akan datang. Sumber daya manusia merupakan penggerak utama bagi setiap perusahaan untuk menjalankan kegiatan atau proses kerja perusahaan. Agar tujuan perusahaan dapat tercapai maka dibutuhkan karyawan yang berkerja secara efisien dan efektif sehingga, memberikan kinerja yang baik.

Menurut Loeke dalam Hartini (2009:211), kinerja pegawai tergantung pada perbedaan antara apa yang diharapkan. Sebaliknya, apabila yang didapat pegawai lebih rendah daripada yang diharapkan akan menyebabkan pegawai tidak memiliki kinerja yang baik. Berdasarkan hasil riset dari beberapa ahli ekonomi di bidang manajemen sumberdaya manusia, ditemukan sekian banyak faktor-faktor sumberdaya manusia yang mempengaruhi kinerja dan beberapa diantaranya yaitu karakteristik individu, motivasi kerja, dan system imbalan

Menurut Mathis \& Jakson (2007), Kinerja Karyawan adalah apa yang di lakukan dan tidak di lakukan oleh karyawan. Kinerja karyawan mempengaruhi keberlangsungan perusahaan tersebut dalam mencapai tujuan perusahaan. Kinerja karyawan yang baik dapat memberikan keuntungan bagi perusahaan, sedangkan kinerja yang buruk dapat menghasilkan kerugian bagi perusahaan. Kinerja yang buruk dapat disebabkan oleh penurunan kinerja karyawan, dan hal ini dapat terlihat ketika karyawan tidak dapat menyelesaikan pekerjaan dengan target dan waktu yang di tentukan oleh perusahaan.

Menurut Mangkunegara (2009:22), Bahwa dalam rangka peningkatan kinerja karyawan terdapat berbagai langkah yang dapat dilakukan, diantaranya adalah dengan mengetahui adanya kekurangan dalam kinerjanya, mengenali kekurangan dan tingkat keseriusan, mengidentifikasikan hal - hal yang mungkin 
dapat menjadi penyebab kekurangan yang berhubungan dengan sistem maupun yang berhubungan dengan karyawan itu sendiri, kemudian mengembangkan rencana tindakan untuk menanggulangi penyebab kekurangan tersebut, melakukan rencana untuk menyelesaikan kekurangan dalam pekerjaan, melakukan evaluasi apakah masalah yang terjadi dapat teratasi, mengetahui apakah kinerja dapat dilakukan sesuai waktu yang direncanakan, dan apakah telah mencapai kinerja yang diharapkan. Langkah - langkah tersebut jika dapat dilaksanakan dengan baik dan teratur, maka kinerja karyawan dapat ditingkatkan. Cara untuk mengetahui peningkatan kinerja karyawan melalui pengukuran kinerja. Menurut Dharma (2003:355), cara - cara pengukuran kinerja karyawan, yaitu:

1. Kuantitas, yaitu jumlah yang harus diselesaikan atau dicapai. Pengukuran kuantitatif melibatkan perhitungan keluaran dari proses atau pelaksanaan kegiatan. Ini berkaitan dengan jumlah keluaran yang dihasilkan.

2. Kualitas, yaitu mutu yang harus dihasilkan (baik tidaknya). Pengukuran kualitatif keluaran mencerminkan pengukuran "tingkat kepuasan", yaitu seberapa baik penyelesaiannya. Ini berkaitan dengan bentuk keluaran.

Dan supaya karyawan dapat memberikan kinerja yang baik maka perusahaan dapat memberikan dukungan baik melalui Karakteristik Individu, Karakteristik individu adalah perbedaan individu dengan individu lainnya. Karakteristik individu didalam perusahaan merupakan suatu hal yang nyata hal tersebut dikarnakan setiap karyawan yang ada di perusahaan memiliki karakter yang berbeda. Karyawan atau sumber daya manusia adalah orang-orang yang memberikan tenaga, bakat, kreativitas, dan usaha mereka kepada perusahaan agar dapat tetap terjaga eksistensinya. Robbins (2008) menyatakan bahwa faktor-faktor yang mudah didefinisikan dan tersedia, data yang dapat diperoleh sebagian besar dari informasi yang tersedia dalam berkas personalia seorang pegawai mengemukakan karakteristik individu meliputi usia, jenis kelamin, banyaknya tanggungan dan masa kerja dalam organisasi.

Lumbunraja (Iskandar,2009:45-46) mengemukakan bahwa karakteristik individu yang berbeda-beda meliputi kebutuhannya, nilai, sikap, dan minat. Perbedaan-perbadaan tersebut dibawa kedunia kerja sehingga motivasi setiap individu berbeda-beda yang akhirnya memberikan karakteristik tersendiri bagi individu tersebut Hasil penelitian sebelumnya mengunkapkan bahwa karakteristik individu berpengaruh posutif dan signifikan terhadap kinerja karyawan ( Handayani,2016)

Selain karakteristik individu, faktor yang berpengaruh terhadap kinerja karyawan adalah motivasi kerja Rendahnya motivasi kerja akan menyebabkan timbulnya kinerja yang rendah. Kinerja karyawan yang rendah tidaklah mungkin mencapai hasil yang baik apabila tidak ada motivasi, karena motivasi itu sendiri merupakan suatu kebutuhan dalam usaha untuk mencapai tujuan perusahaan. Sedangkan bagi karyawan yang memiliki motivisi kerja yang tinggi membuat dirinya merasa senang dan memperoleh kepuasan tersendiri dalam 
pekerjaannya, seorang karyawan akan lebih berusaha untuk mendapatkan hasil yang maksimal dengan semangatnya yang tinggi, serta selalu berusaha mengembangkan tugas dan dirinya (Anoraga, 2009). Hasil penelitian empiris menunjukkan bahwa variabel motivai kerja mempengaruhi variabel kinerja kraywan (Octavianasari ,2017)

Teori motivasi yang digunakan dalam penelitian ini adalah Teori ERG atau Alderfer's Existence, Relatedness and Growth (ERG) Theory. Teori ini dikemukakan oleh Clayton Alderfer seorang ahli dari Yale University. Teori ini merupakan penyempurnaan dari teori hirarki kebutuhan Maslow. Alderfer mengemukakan dalam Mangkunegara (2009:98), bahwa ada 3 kelompok kebutuhan utama yaitu:

1) Kebutuhan akan eksistensi (Existence Needs) Kebutuhan yang mencakup semua tipe keinginan - keinginan fisik atau fisiologis dari eksistensi pegawai, seperti makan, minum, tempat berlindung pakaian, bernafas, gaji, dan keamanan kondisi kerja. Untuk memenuhi kebutuhan tersebut maka seorang individu akan termotivasi untuk bekerja keras.

2) Kebutuhan akan afiliasi (Relatedness Needs) Merupakan kebutuhan interpersonal, yaitu kepuasan dalam berinteraksi di lingkungan kerja. Menurut Thoha (2015), menjelaskan bahwa "kebutuhan berhubungan adalah suatu kebutuhan untuk menjalin hubungan sesamanya dan melakukan hubungan sosisal sama dengan orang lain." Pada dasarnya interaksi sosial tidak terlepas dari perilaku manusia sebagai makhluk sosial, dimana manusia tidak dapat bertahan sendiri tanpa bantuan orang lain.

3. Kebutuhan akan pertumbuhan (Growth Needs) Kebutuhan untuk tumbuh, mengembangkan, dan meningkatkan kemampuan kemampuan serta kecakapan individu karyawan hingga mencapai potensi atau hasil kerja secara maksimal.

Selain itu, dalam meningkatkan kinerja karyawannya perusahaan akan melakukan beberapa cara yang dapat mendorong karyawan untuk bekerja secara maksimal diantaranya pemberian imbalan Kepuasan atas kompensasi dapat mempengaruhi perilaku karyawan untuk bekerja lebih bersemangat dan memacu tingginya kinerja (Handoko, 2012).

Imbalan atau kompensasi adalah faktor penting yang mempengaruhi bagaimana dan mengapa orang-orang bekerja pada suatu organisasi dan bukan pada organisasi lainnya. Perusahaan menyediakan berbagai penghargaan (reward) yang akan diberikan kepada mereka yang berprestasi dalam bidang kerja masing-masing. Oleh karena itu para manajer pun akan lebih terdorong untuk berprestasi mencapai target anggarannya dengan harapan akan memperoleh imbalan dari perusahaan.

Menurut Suryo imbalan dapat diberikan kepada karyawan dalam empat macam, yakni :

1. Upah Dan Gaji

Merupakan bentuk pembayaran yang biasanya diberikan berdasarkan jumlah jam kerja, semakin banyak jam kerja semakin besar upah yang diterima. 
Sedangkan gaji besarnya tetap tanpa mempertimbangkan jam kerja. Analisis dampak imbalan dan kepuasan kerja terhadap kinerja pegawai.

2. Program Insentif

Imbalan yang diterima karyawan selain gaji dan upah antara lain dalam bentuk insentif, yang biasanya diberikan berdasarkan tingkat keberhasilan perusahaan baik dalam mencapai tingkat penjualan, tingkat keuntungan atau tingkat produktivitas.

3. Employee Benefit Program / Tunjangan

Merupakan imbalan tidak langsung yang diberikan perusahaan kepada karyawan seperti program asuransi jiwa dan kesehatan, program pensiun, biaya liburan dan sebagainya.

4. Perqusites

Umumnya hanya diberikan kepada karyawan yang menduduki level cukup tinggi dalam bentuk fasilitas yang diberikan perusahaan seperti kendaraan dinas, perumahaan, keanggotaan klub olahraga, biaya perjalanan dinas dan bentukbentuk fasilitas lain.

Berdasarkan pengamatan awal dan wawancara terhadap informan yang dilakukan oleh peneliti, diperoleh informasi bahwa adanya permaalahan dimana kinerja karyawan saat ini masih perlu ditingkatkan. Hal ini didukung dengan suatu fakta dimana tingkat absensi karyawan yang menurun. adanya tingkat turn over yang semakin tinggi, datang ke ketempat kerja tidak tepat waktu, Selain itu pencapaian tugas karyawan seringkali tidak sesuai dengan standar waktu yang telah ditentukan untuk menyelesaikan pekerjaan. tugas - tugas yang diberikan seringkali tidak dapat diselesaikan dengan tepat waktu.pencatatan stoc yang seringkali terjadi kesalahan Fenomena ini menunjukkan bahwa kinerja karyawan masih rendah

Dari kondisi tersebut perlu dikaji secara empiris apakah karakteristik individu, motivasi kerja karyawan serta system imbalan yang menjadi faktor yang berpengaruh terhadap penurunan kinerja tersebut.

\section{Metode Penelitian}

\section{Lokasi Penelitian}

Lokasi penelitian yang dipilih adalah perusahaan supermarket yang ada di kota Gorontalo sebanyak enam Supermarket. Lokasi tersebut dipilih karena beberapa pertimbanagn antara lain : 1). Kota Gorontalo adalah provinsi yang sedang giat - giatnya membangun, 2). Sebagai Provinsi baru, maka tentunya ketersediaan sarana pembelanjaan yang memadai terus diupayakan oleh pemerintah melalui dunia usaha untuk dikembangkan.

Populasi dan Sampel Penelitian. 
Populasi dalam penelitian ini adalah keseluruhan karyawan Supermarket yang ada di Provinsi Gorontalo dengan jumlah Supermarket 6 Buah dengan total karyawn 2367 Orang. Penentuan jumlah sampel yang akan menjadi sampel ditetapkan dengan menggunakan Rumus Slovin (Husain Umar,2004) Berdasarkan formulasi diatas, maka jumlah sampel minimal yang harus diperoleh adalah 342 responden

\section{Teknik Pengumpulan Data}

Adapun teknik yang digunakan untuk mengumpulkan data dalam penelitian ini adalah :

1. Wawancara,

2. Kuisioner,

\section{Teknik analisis Data}

Langkah berikutnya sebelum menarik kesimpulan adalah menanalisisdata yang diperoleh dari penelitian lapangan. Berdasarkan hipotesis yang diajukan metode analisis yang digunakan dalam penelitian ini adalah analisis Jalur atau path analysis menggunakan beberapa asumsi dan sejumlah langkah - langkah yang harus ditempuh

\section{Hipotesis Penelitian}

Berdasarkan tinjauan pustaka, penelitian terdahulu, dan kerangka konseptual, maka hipotesis dalam penelitian ini adalah:

1. Variabel karakteristik individu (X1), motivasi kerja (X2) dan sistem imbalan(X3) secara simultan berpengaruh signifikan terhadap kinerja karyawan.

2. Variabel karakteristik individu (X1), motivasi kerja (X2) dan sistem imbalan(X3) secara parsial berpengaruh signifikan terhadap kinerja karyawan.

\section{Hasil Penelitan dan Pembahasan Analisis Data Statistik.}

Untuk mengetahui pengaruh motivasi terhadap kinerja Pada karyawan maka berikut ini akan dikemukakan analisis hasil statistk. Hasil analisis tersebut akan diketahui apakah variabel-variabel bebas (Independen) memberikan pengaruh yang nyata (signifikan) terhadap variabel terikat (dependen). Hasil olahan data kerangka hubungan kausal antara X1,X2, dan X3 tehadap Y dapat dibuat melalui persamaan struktural sebagai berikut :

$$
Y=0,619 X 1+0,704 X 2+0,724+0,240 \varepsilon
$$

Untuk mengetahui hubungan antar variabel dapat diketahui dari Gambar dibawah ini :

Dari persamaan diatas, menunjukkan bahwa koefisien variabel independen dapat dijelaskan sebagai berikut :

1. Variabel karakteristik individu (X1) sebesar 0,619 dan bertanda positif, menandakan bahwa karakteristik individu (X1),memiliki kontribusi yang positif terhadap kinerja karyawan (Y). Artinya, bahwa apabila karakteristik individu meningkat satu satuan, maka kinerja karyawan (Y) meningkat sebesar 0,619 
2. Variabel motivasi kerja (X2) sebesar 0,704 dan bertanda positif, menandakan motivasi kerja (X2), memiliki kontribusi yang positif terhadap kinerja karyawani (Y). Artinya, bahwa apabila motivasi kerja meningkat satu satuan, maka kinerja karyawan (Y) meningkat sebesar 0,704

3. Variabel sistem imbalan (X3) sebesar 0,724 dan bertanda positif, menandakan sistem imbalan (X2), memiliki kontribusi yang positif terhadap kinerja karyawani (Y). Artinya, bahwa apabila sistem imbalan meningkat satu satuan, maka kinerja karyawan (Y) meningkat sebesar 0,724

4. Koefisien Determinasi (R Square). sebesar 0,760, menunjukkan bahwa sekitar $76,0 \%$ pengaruh yang ada terhadap kinerja karyawan dijelaskan oleh variabel karakteristik individu,motivasi kerja dan sistem imbalan serta masih ada sekitar $24 \%$ ditentukan oleh variabel lain yang tidak diteliti dalam penelitian ini

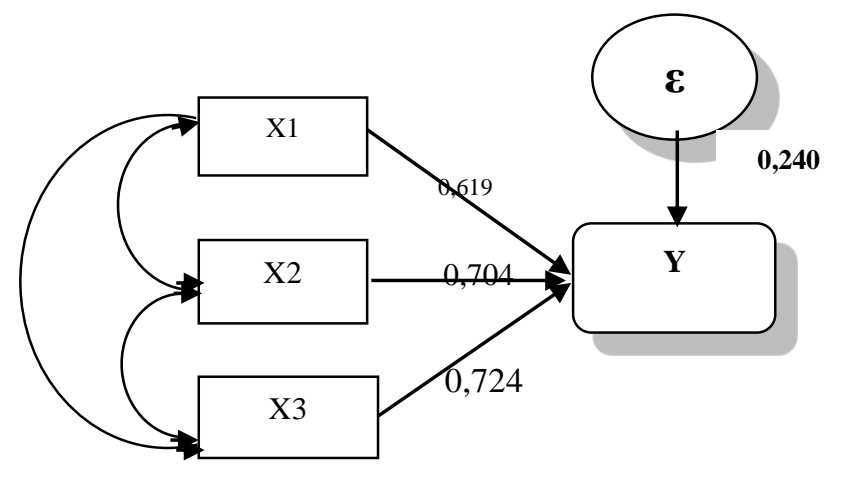

Gambar 4.1. Hubungan antara X1, X2 dan X3 terhadap Y

Dari Gambar 4.1. dapat dijelaskan bahwa karakteristik individu secara parsial memiliki pengaruh sebesar 0,619 atau 61,9\%, Variabel motivasi secara parsial memiliki pengaruh sebesar 0,704 atau sekitar $70,4 \%$, variabel sistem imbalan secara parsial memiliki pengarug sebesar $0,72,4$ atau $72,4 \%$. Dan secara simultan ketiga faktor tersebut memberikan pengaruh sebesar 0,760 atau 76,0\%. Serta masih ada faktor lain yang beroengaruh namun tidak terdapat dalam model sebesar 0,240 atau $24 \%$

\section{Pengujian Hipotesis \\ Pengujian Hipotesis secara simultan.}

Dari hasil pengolahan data dengan menggunkana program SPSS vs 20.0, uji siginifikansi analisis jalur dengan membandingkan antara probabilitas 0,05 dengan probabilitas sig dengan dasar pengambilan keputusan bahwa jika nilai probabilitas 0,05 lebih kecil atau sama dengan nilai probabilitas sig $(0,0 \mathrm{~s}<\mathrm{sig})$, maka Ho diterima, artinya tidak signifikan, sebaliknya, jika nilai probabilitas 0,05 
lebih besar atau sama dengan nilai probabilitas sig atau $(0,05>$ sig), maka Ho ditolak dan Ha diterima artinya signifikan.

Dari hasil olahan data diperoleh nilai sig F sebesar 0,000 dengan nilai probabilitas 0,05 . Karena nilai sig < 0,05, maka keputusannya adalah Ha diterima sehingga terbukti bahwa variabel karakteristik individu (X1), motivasi kerja (X2) dan sistem imbalan (X3) berpengaruh secara simultan dan signifikan terhadap kinerja karyawan (Y).

Pengujian Hipotesis secara parsial.

a. Karakteristik Individu (X1) berpengaruh signifikan terhadap Kinerja karyawan (Y).

Hasil olahan data diperoleh bahwa karakteristik individu mempunyai nilai sig sebesar 0,000, kemudian dibandingkan dengan nilai probabilitas 0,05, ternyata nilai probabilitas 0,05 lebih besar dengan nilia probabilitas sig atau $(0,05>0,000)$ maka Ho ditolak artinya signifikan. Jadi terbukti bahwa karakteristik individu (X1) berpengaruh secara signifikan terhadap kinerja karyawan (Y). Artinya bahwa apabila karyawan memiliki karakteristik individu yang baik, akan mampu meningkatkan kinerja karyawan

b. Motivasi Kerja (X2) berpengaruh signifikan terhadap Kinerja karyawan (Y).

Hasil olahan data diperoleh bahwa motivasi kerja nilai sig sebesar 0,001, kemudian dibandingkan dengan nilai probabilitas 0,05 , ternyata nilai probabilitas 0,05 lebih besar dengan nilia probabilitas sig atau $(0,05>0,000)$ maka Ho ditolak artinya signifikan. Jadi terbukti bahwa motivasi kerja (X2) berpengaruh secara signifikan terhadap kinerja karyawan (Y). Artinya bahwa apabila karyawan memiliki motivasi yang tinggi maka akan meningkatkan kinerjanya.

c. Sistem Imbalan (X3) berpengaruh signifikan terhadap Kinerja karyawan (Y).

Hasil olahan data diperoleh bahwa motivasi ekstrinsik memiliki nilai sig sebesar 0,000, kemudian dibandingkan dengan nilai probabilitas 0,05, ternyata nilai probabilitas 0,05 lebih besar dengan nilia probabilitas sig atau $(0,05>0,000)$ maka Ho ditolak artinya signifikan. Jadi terbukti bahwa sistem imbalan (X3) berpengaruh secara signifikan terhadap kinerja karyawan (Y). Artinya bahwa semakin tinggi imbalan yang diberikan kepada karyawan, maka akan meningkatkan kinerja karyawan

\section{Pembahasan}

Potensi Sumber daya manusia pada hakekatnya adalah salah satu modal dasar pembangunan nasional. Sumber daya manusia merupakan daya yang bersumber dari manusia. Karena Sumber daya manusia merupakan aset utama suatu organisasi yang menjadi perencana dan pelaku aktif dari setiap aktivitas organisasi.

Usaha yang dapat dilakukan pekerja sebagai individu dipengaruhi oleh jenis dan kualitas kemampuan yang dimilikinya, yang diwujudkannya berupa keterampilan atau keahlian dalam bekerja. Berdasarkan jenis dan kualitas keterampilan/keahlian dalam bekerja akan diperoleh hasil, yang jika sesuai dengan harapan akan dirasakan sebagai ganjaran yang memberikan rasa kepuasan. 
Motivasi dikatakan sebagai energi untuk membangkitkan dorongan dalam diri. Dalam hubungannya dengan lingkungan kerja motivasi kerja disefinisikan sebagai kondisi yang berpengaruh membangkitkan, mengarahkan, dan memelihara perilaku yang berhubungan dengan lingkungan kerja. Motivasi tidak terlepas dari kebutuhan dan kebutuhan dapat didefinisikan sebagai suatu kesenjangan atau pertentangan yang dialami antara suatu kenyataan dengan dorongan yang ada dalam diri . Apabila kebutuhan karyawan tidak terpenuhi, maka pegawai akan menunjukkan perilaku yang kecewa. Sebaliknya, jika kebutuhannya terpenuhi, maka pegawai tersebut akan memprlihatkan perilaku yang gembira sebagai manifestasi dari rasa kepuasan dirinya.

Hasil penelitian ini menunjukkan bahwa motivasi berpengaruh terhadap kineja karyawan. Hal ini menunjukkan bahwa untuk mencapai kinerja yang tinggi perlu memiliki motivasi, kemampuan yang tinggi, dan pengalaman yang memadai. Jadi pemberian dan penerapan motivasi oleh pimpinan kepada karyawan selama ini menunjukkan tingkat yang cukup baik dan mencerminkan tingkat pelayanaan yang baik pula. Pemberian motivasi, baik dari pimpinan maupun dari diri pegawai diharapkan akan mempengaruhi kinerja yang optimal dan mampu memberiakn pelayanan kepada masyarakat yang memuaskan.

Hasil penelitian ini menunjukkan bahwa pemberian imbalan mempunyai pengaruh yang signifikan terhadap kinerja karyawan. Artinya bahwa semakin tinggi imbalan yang diberikan maka akan mampu meningkatkan kinerjanya. Jadi imbalan yang diterima karyawan baik imbalan intrinsic, maupun imbalan ekstrinsik umumnya dihargai berdasarkan prestasinya. Hai ini sejalan dengan pendapat yang mengatakan bahwa pemberian imbalan baik imbalan intrinsic maupun imbalan ekstrinsik lebih memacu karyawan untuk memotivasi diri terbukti bahwa adanya hubungan positif anatar motivasi dengan kinerja karyawan.

\section{Penutup}

Berdasarkan hasil pengolahan data yang telah dilakukan pada bab sebelumnya sehubungan dengan pengaruh karakteristik individu, motivasi kerja dan sistem imbalan, sebagai variabel bebas dengan kinerja karaywan pada Supermarket di Gorontalo, maka penulis dapat menarik beberapa kesimpulan sebagai berikut :

1. Berdasarkan hasil uji $\mathrm{F}$ secara simultan karakteristik individu (X1), motivasi kerja (X2) dan sistem imbalan memiliki kontribusi yang positif dan signifikan terhadap kinerja karyawan. sebesar 76,0\%. Sisanya yaitu sebesar 24,0 \% merupakan pengaruh yang datang dari faktor - faktor yang tidak diteliti. Berdasarkan hasil penelitian ini dapat disimpulkan bahwa hipotesis penelitian ini yang menyatakan bahwa karakteristik individu (X1), motivasi kerja (X2) dan sistem imbala3 (X2) berpengaruh secara simultan dan signifikan terhadap kinerja karyawan dapat diterima

2. Karakteristik individu (X1) yang diukur oleh kinerja karyawan (Y) memiliki kontribusi yang positif dan signifikan terhadap tinggi rendahnya kinerja karyawan . Besarnya kontribusi karakteristik individu yang secara langsung berkontribusi terhadap kinerja karyawan sebesar $61,9 \%$ terhadap kinerja karyawan. Jadi dapat disimpulkan bahwa hipotesis yang 
menyatakan karakteristik individu berpengaruh secara signifikan dapat diterima

3. Motivasi keja (X2) yang diukur oleh kinerja karyawan (Y) memiliki kontribusi yang positif dan signifikan terhadap tinggi rendahnya kinerja karyawan. Besarnya kontribusi motivasi kerja yang secara langsung berkontribusi terhadap kinerja karyawan sebesar 70,4\% terhadap kinerja karyawan.. Jadi dapat disimpulkan bahwa hipoesis yang menyatakan motivasi kerja berpengaruh secara signifikan dapat diterima

4. Sistem Imbalan (X3) yang diukur oleh kinerja karyawan (Y) memiliki kontribusi yang positif dan signifikan terhadap tinggi rendahnya kinerja karyawan. Besarnya kontribusi sistem imbalan yang secara langsung berkontribusi terhadap kinerja karyawan sebesar 72,4 \% terhadap kinerja karyawan.. Jadi dapat disimpulkan bahwa hipoesis yang menyatakan system imbalan berpengaruh secara signifikan dapat diterima

Saran

1. Berdasarkan hasil penelitian penulis menyarankan kepada pempinan memperhatikan faktor motivasi sebab akan mendorong karyawan untuk konsisten terhadap waktu kerja (penggunaan jam kerja dan tingkat penyelesaian pekerjaan), sehingga pekerjaan dapat diselesaikan dengan tepat waktu. Motivasi yang tinggi akan mendorong pegawai bersemangat untuk bekerja, sehingga pekerjaan dapat diselesaikan sesuai ketentuan yang ditetapkan.

2. Disarankan kepada peneliti selanjutnya unruk meneliti faktor - fakktor yang mempenharuhi kinerja selain motivasi

\section{DAFTAR PUSTAKA}

Anoraga, P. (2009). Psikologi Kerja. Jakarta: Rineka Cipta

Arikunto, Suharsimi. 2006. Prosedur Penelitian Suatu Pendekatan Praktek, Jakarta: Rineka Cipta.

Dharma,A. (2003). Manajemen Supervisi: Petunjuk Praktis Bagi Para Supervisor. Jakarta: Raja Grafindo Persada

Gomes, Faustino Cardoso. 2003. Manajemen Sumber Daya Manusia. Yogyakarta: Andi

Handayani,Ratna,2016, Pengaruh Karakteristik Individu terhadap Kinerja karyawan,Jurnal Penelitian Manajemen dabn Akuntansi,Vol.1 No.2, 2016

Handoko, T., Hani. (2012).Manajemen Personalia dan Sumber Daya Manusia, Yogyakarta: Penerbit BPFE.

Hartini, Hariandja, 2009. Metode Pengembangan Sumberdaya Manusia Melalui Semangat Kerja, Andi Offset, Jakarta. 
Husain Walidun. 2011. Participative Leadership. Bandung : MQS Publising

Iskandar, 2016. Pengaruh Karakteristik Individu, Beban Kerja, dan Lingkungan kerja Terhadap Kinerja Pegawai Inspektorat Provinsi Sulawesi Tangah, Jurnal Katalogis Volume 5 Nomor 1 Januari 2017,

Leoni Saputri, Darnita,2018, Hubungan kompensasi dengan kinerja karyawan, Jurnal JOM Fisip,Vol. 5 No. 1, April,2018

Mangkunegara, A. Anwar Prabu, 2009. Manajemen Sumber Daya Manusia Perusahaan, Bandung :PT. Remaja Rosdakarya

Manulang M, 2002. Manajemen Personalia, Balai Pustaka, Jakarta

Mathis dan Jackson. (2007). Manajemen Sumber Daya Manusia, Edisi Pertama. Cetakan Pertama. Yogyakarta : Salemba Empat

Octavianasari, Putri, 2017, Pengaruh Motivasi terhadap kinerja karyawan, Skripsi, Fakultas Psikologi Universitas Muhammadiyah Surakarta

Robbins, Stephen,2008,Perilaku Organisasi,Edisi 12, Jakarta, Salemba Empat

Saydam, Gouzali. 2005. Manajemen Sumber Daya Manusia. Jakarta : PT Gunung Agung

Simamora,Henry. 2004. Manajemen Sumber Daya Manusia-Edisi III Yogyakarta: YKPN

Suryo,P.R, 2007, Analisis Dampak Imbalan dan kepuasan Kerja Terhadap Kinerja Pegawai Sekretariat Daerah Kabupaten Kutai Timur

Sukandarrumidi, 2002. Metode Penelitian. Yogyakarta. UGM Press

Thoha, M. (2015). Perilaku Organisasi: Konsep Dasar dan Aplikasinya. Jakarta: PT Raja Grafindo Persada 